\title{
Effect of Prehydrolysis of Milk Fat on its Conversion to Biogas
}

\author{
M. Sage, ${ }^{*}$ G. Daufin, $¥ \ddagger$ and G. Gesan-Guiziou $\ddagger^{1}$ \\ *Ondéo-Degrémont 87 chemin des rondes, 78310 Croissy sur Seine, France \\ fl'Institut National de la Recherche Agronomique, UMR1253, Science et Technologie du Lait et de l'Oeuf, 65 rue de saint Brieuc, F-35000 \\ Rennes, France \\ $\ddagger$ Agrocampus Rennes, UMR1253, F-35000 Rennes, France
}

\section{ABSTRACT}

Milk fat is considered to be the main limiting component of the kinetics of dairy wastewater anaerobic digestion. The objective of this work was to give a better understanding of the nonelucidated anaerobic degradation steps of milk fat. For that purpose, the kinetics of fat degradation was quantified in comparison with other milk components (lactose, proteins), regarding the milk fat polluting load and structure [globular (native state), triglycerides]. This work confirms that milk fat is degraded after a lag phase of several days, with a maximal degradation rate 2 to 5 times less than the degradation rate of the other milk components. It was shown that (1) the structure of the fat does not influence the limits of its anaerobic degradation; (2) the lag phase before biogas production is mainly due to unsaturated free fatty acids (FFA); and (3) conversion to biogas occurs at a lower rate for saturated than for unsaturated FFA. Therefore, the prehydrolysis of fat, which increases the instantaneous concentration of unsaturated FFA, sharply increases the length of the lag phase with no significant change in the maximal biogas production rate. To reduce the delay imposed in the biogas production, it is necessary to reduce the concentration of unsaturated FFA.

Key words: milk fat, hydrolysis, methanization, anaerobic degradation

\section{INTRODUCTION}

Due to stricter environmental regulations, the dairy industry is pushed to reduce both the volume ( 1 to 5 L per liter of processed milk) and the polluting load [0.5 to $5 \mathrm{~g} / \mathrm{L}$ of chemical oxygen demand (COD)] of its wastewater reaching water treatment stations. The polluting load is mainly composed of milk components that can easily be converted into energy (biogas) by methanization (Li et al., 1984; Gutierrez et al., 1991).

Received December 7, 2007.

Accepted June 5, 2008.

${ }^{1}$ Corresponding author: genevieve.gesan-guiziou@rennes.inra.fr
Among the milk components, milk fat, which represents 4 to $22 \%$ of the dry matter of the dairy process waters (Sage, 2005), is often considered as the main limiting component of the kinetics of dairy wastewater anaerobic digestion (Petruy and Lettinga, 1997; Vidal et al., 2000). Therefore, fat is usually separated from the waste waters and degraded with biological aerobic digestion generating extra costs: aeration for aerobic digestion and further sludge treatment processes. Moreover, because of the high specific COD of the milk fat (about $2 \mathrm{~kg}_{\mathrm{COD}} / \mathrm{kg}_{\text {fat }}$ ), its removal leads to 8 to $44 \%$ potentially lost energy (methane) compared with anaerobic digestion.

Little has been reported on the comparison of anaerobic degradation kinetics of milk fat and other milk components (Perle et al., 1995; Vidal et al., 2000). Perle et al. (1995) have shown that at similar polluting load the maximum production rate of biogas from caseins, amino acids, and VFA is 2 times greater than production rate obtained from oleic acid [major milk long-chain fatty acid (LCFA)] and 4 times greater than the production rate obtained from anhydrous milk fat (AMF).

Milk fat is mainly composed of fat globules and is constituted by more than $97 \%$ of triglycerides (esters of fatty acid and glycerol, neutral hydrophobic molecules). Its anaerobic degradation follows the same steps as in aerobic digestion (Figure 1). Biodegradation is initiated by lipid hydrolysis (Weng and Jeris, 1976): hydrolysis of triglycerides to FFA and glycerol. Glycerol is metabolized to propionate; FFA are degraded into acetate and hydrogen through $B$-oxidation, after a saturation step in the case of unsaturated acids. Acetate and $\mathrm{H}_{2}$ are then converted to methane by acetoclastic and hydrogenotrophic methanogens in the methanogenesis step.

The impact of milk fat in the anaerobic degradation process is complex and 2 major limitations have been reported: physical and chemical inhibition.

\section{Physical Inhibition}

Milk fat globules mostly contain triglycerides, the neutral structure of which limits their solubility in 


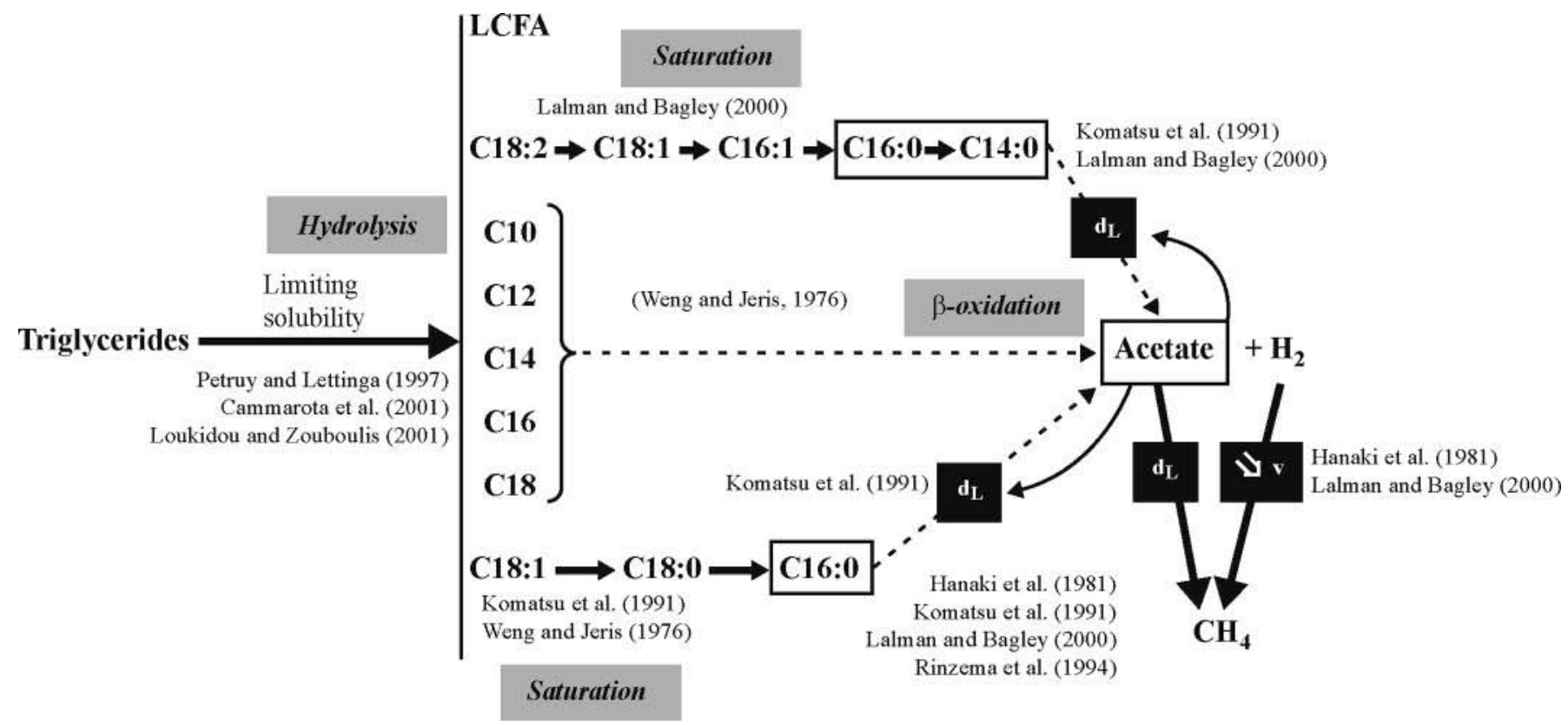

Figure 1. Limiting steps of anaerobic degradation of milk fat from triglyceride to methane. This figure is a synthesis of literature information available for each step of the degradation: hydrolysis of triglycerides; saturation of unsaturated fatty acids; successive 6 -oxidations of saturated fatty acids (C10 to C18) and corresponding inhibition due to the acetate produced; conversion of acetate to methane. Dotted lines indicate several reaction steps. White boxes $=$ accumulation; black boxes $=$ consequence of inhibitions; $d_{L}=$ lag phase; $\Downarrow_{\mathrm{V}}=$ decrease of conver sion velocity; $\mathrm{LCFA}=$ long-chain fatty acids; $\mathrm{C} 10=$ capric acid; $\mathrm{C} 12=$ lauric acid; $\mathrm{C} 14=$ myristic acid; $\mathrm{C} 16=$ palmitic acid; $\mathrm{C} 18=$ stearic acid; C16:1 = palmitoleic acid; C18:1 = oleic acid; C18:2 = linoleic acid.

the aqueous phase (Petruy and Lettinga, 1997). This low solubility leeds to adsorption of fat into biomass, decantation difficulties (Vidal et al., 2000), low bioassimilability and low accessibility of other substrates to bacteria (Petruy and Lettinga, 1997). Hanaki et al. (1981) and Petruy and Lettinga (1997) showed, in batch mode, that the anaerobic digestion of a mixture of long chain fatty acid, LCFA (C10-C18, $0.35 \mathrm{~kg}_{\mathrm{LCFA}} /$ $\mathrm{kg}_{\text {VSs }}$ [VSS (volatile suspended solids); $40 \%$ of saturated acids (weight basis), 60\% of unsaturated acids] led actually to a $60 \%$ temporary aggregation of LCFA and then to a lag phase of $10 \mathrm{~d}$ before methane production.

\section{Chemical Inhibition}

Chemical inhibition can be due to the toxicity of a given number of fatty acids on anaerobic microorganisms. Hanaki et al. (1981) showed that FFA (C10 to C18, $40 \%$ saturated, $60 \%$ unsaturated) inhibit $\mathrm{H}_{2}$-producing bacteria responsible for B-oxidation on one hand, and acetoclastic (acetate $\rightarrow \mathrm{CH}_{4}$ ) and hydrogenotrophic $\left(\mathrm{H}_{2} \rightarrow \mathrm{CH}_{4}\right)$ methanogens on the other hand. Furthermore, the inhibition of hydrogenotrophic archaea leads to a reduction of the rate of hydrogen conversion into methane, which is correlated to FFA concentration (Lalman and Bagley, 2000). The inhibition of acetogens and acetoclastic methanogens leeds to a pronounced lag phase. The inhibition intensity varies with FFA nature (chain length and number of $\mathrm{C}=\mathrm{C}$ double bond; Kim et al., 2004). Koster and Cramer (1987) showed that LCFA (C10, C12, C14, C18:1) have a variable toxicity power onto methanogens: $\mathrm{C} 12$ and $\mathrm{C} 18: 1$ (30\% of milk fatty acids) are the more toxic acid and the presence of sub-toxic concentration of $\mathrm{C} 10$ enhances $\mathrm{C} 12$ and C14 toxicity. Hanaki et al. (1981) observed a similar synergic effect with C18:1 and a LCFA mixture (C10 to $\mathrm{C} 18,40 \%$ saturated, $60 \%$ unsaturated). Komatsu et al. (1991) also reported that the lag phase length before biogas production from a given chain length FFA increases with the number of its double bonds (C18:0, C18:1, C18:2).

The exact mechanisms implied in the inhibitions described are complex (Figure 1) and not yet fully elucidated. It seems as if inhibitions occur in the very early steps of LCFA degradation, which vary according to the LCFA nature. In the case of milk fat, inhibitions observed during anaerobic degradation seem to be mainly due to the presence of unsaturated fatty acids. Indeed, C18:1 (30\% in mass) and C18:2 (3\%) were reported to cause a significant lag phase before acidification and methanogenesis, which is not the case with C18:0 (14\%), C16:0 (27\%), and C:14:0 (11\%; Komatsu 
et al., 1991). The individual mass fraction of other fatty acids represents only a small fraction (3\%) of milk fat (Lopez, 2001).

However, the biochemical steps of the anaerobic digestion of the milk fat, which limit the kinetics of the degradation, are not clearly highlighted. Hanaki et al. (1981) showed in batch mode, that the milk fat is quickly hydrolyzed into FFA, the degradation of which is limiting. Petruy and Lettinga (1997) showed the opposite with an expanded granular sludge bed reactor: the solubilization (hydrolysis) rate limits the global kinetic of the anaerobic conversion of AMF to biogas.

The objective of this work was to give a better understanding of the degradation steps, which limit the degradation kinetics and of the mechanisms of milk fat anaerobic degradation. A better understanding of these phenomena is necessary to improve the degradation of milk fat in the anaerobic processes used in wastewater treatment plants. For that purpose, the kinetics of milk fat degradation was quantified in comparison to other milk components, regarding the milk fat polluting load and structure: globular (native state), triglycerides, FFA, and surfactant monoglycerides (hydrolyzed fat).

\section{MATERIALS AND METHODS}

\section{Biomass and Enzymes}

Anaerobic Biomass. The anaerobic biomass used was taken from an anaerobic sludge digester of a distillery wastewater treatment plant (Revico, St Laurent de Cognac, France). Sludge was initially acclimated over $60 \mathrm{~d}$ to commercial UHT semiskim milk (see Substrates section) in a 15-L stirred (300 rpm) sequencing batch reactor at $36 \pm 1^{\circ} \mathrm{C}$.

The reactor was filled with sludge containing $(\mathrm{kg} /$ $\mathrm{m}^{3}$ ) suspended solids $(\mathrm{SS})=15.0 \pm 0.1, \mathrm{VSS}=9.3 \pm$ 0.1 , and soluble COD $=0.56 \pm 0.01$. Hydraulic retention time was equal to sludge retention time and equal to $30 \mathrm{~d}$. Cycle length was $24 \mathrm{~h}$ and the applied load was $0.2 \mathrm{~kg}_{\mathrm{COD}} / \mathrm{kg}_{\mathrm{VSS}} / \mathrm{d}$. In these steady state conditions, the biogas production was $6 \pm 1 \mathrm{~L}_{\text {biogas }} / \mathrm{d}\left(60 \pm 2 \% \mathrm{CH}_{4}\right)$. The biogas yield was $0.30 \pm 0.06 \mathrm{~m}^{3} \mathrm{CH}_{4} / \mathrm{kg}_{\text {CODa }}$ (CODa is the total added COD at the beginning of the batch experiment), which indicated good anaerobic degradation and biomass performance similar to values usually reported.

Lipase. Lipex (EC 3.1.1.3), provided by Novozymes (Bagsvanrd, Danemark) is produced by fermentation of a genetically modified Aspergillus strain designed to be used as an additive in detergents. It hydrolyses triglycerides ester links in position 1 and 3 and hence produces monoglycerides, diglycerides and FFA. Its ac- tivity at $30^{\circ} \mathrm{C}$ and $\mathrm{pH} 7$ on tributyrin is $100 \mathrm{kLU}$ (kilo lipase unit)/g, as determined by Novozymes.

\section{Substrates}

Dairy Substrates. Thermized cream (EntremontAlliance, Montauban de Bretagne, France) was stored at $4^{\circ} \mathrm{C}$ and used and characterized within $48 \mathrm{~h}$ after its production. Its characteristic was $\left(\mathrm{kg} / \mathrm{m}^{3}\right): \mathrm{COD}=880$ \pm 16 ; fat $=423 \pm 7$; dry matter $=478 \pm 7$; and ash $=0.42$ \pm 0.03 .

Anhydrous milk fat was purchased from Lactalis (Petit-Fayt, France). Commercialized UHT semi-skim milk purchased from a local store contained $\left(\mathrm{kg} / \mathrm{m}^{3}\right)$ : $\mathrm{COD}=120$, protein $=31.5$, lactose $=50$, and fat $=15.5$, according to the manufacturer. Commercial UHT skim milk contained $\left(\mathrm{kg} / \mathrm{m}^{3}\right)$ : COD $=96$, proteins $=31.5$, lactose $=48$, and fat $=1$, according to the manufacturer.

Hydrolyzed Substrates. Thermized cream and anhydrous milk fat were hydrolyzed to study the effect of hydrolysis on anaerobic degradation. Hydrolysis was performed in a $2-\mathrm{L}$ reactor (reaction volume $=0.5 \mathrm{~L}$, SGI, Toulouse, France). Temperature was regulated at $30 \pm 1^{\circ} \mathrm{C}$. The $\mathrm{pH}$ was maintained at $7.00 \pm 0.05$ with a pHstat device (dosimat 665, Metrohm, Herisau, Switzerland) using $\mathrm{NaOH}(3 M)$.

The degrees of hydrolysis (DH) obtained at the end of the experiments $(4 \mathrm{~h})$ were $64 \pm 3 \%$ for $\mathrm{AMF}$ and $54 \pm 3 \%$ for thermized cream. The $\mathrm{DH}$ represents the proportion of the initial substrate converted into FFA and was determined by the following equation:

$$
D H(k g / k g)=\frac{m_{F F A}}{m_{F M}},
$$

where $\mathbf{m}_{\mathrm{FFA}}=$ mass of FFA determined at the end of the hydrolysis experiment; $\mathbf{m}_{\mathrm{FM}}=$ mass of fatty matter (thermized cream or AMF), measured at the beginning of the hydrolysis experiment.

Fatty Acids. The main compounds produced by dairy fat hydrolysis [palmitic (C16:0) and oleic (C18:1) acids (99\% Sigma Chemical, St. Louis, MO)] were used to clarify the origin of the phenomenon observed during dairy fat anaerobic degradation. The C16:0 and C18:1 underwent anaerobic degradation at a substrate to biomass ratio of 1.2 and $0.8 \mathrm{~kg}_{\mathrm{COD}} / \mathrm{kg}_{\mathrm{VSS}}$, respectively. These ratios were similar to saturated and unsaturated fatty acids to biomass ratios during the anaerobic degradation of fat at a total substrate to biomass ratio of $2.0 \mathrm{~kg}$ COD $/ \mathrm{kg}_{\mathrm{VSS}}$. These ratios allowed quantifying the effects of saturated and unsaturated fatty acids on the anaerobic degradation in their right proportions. 


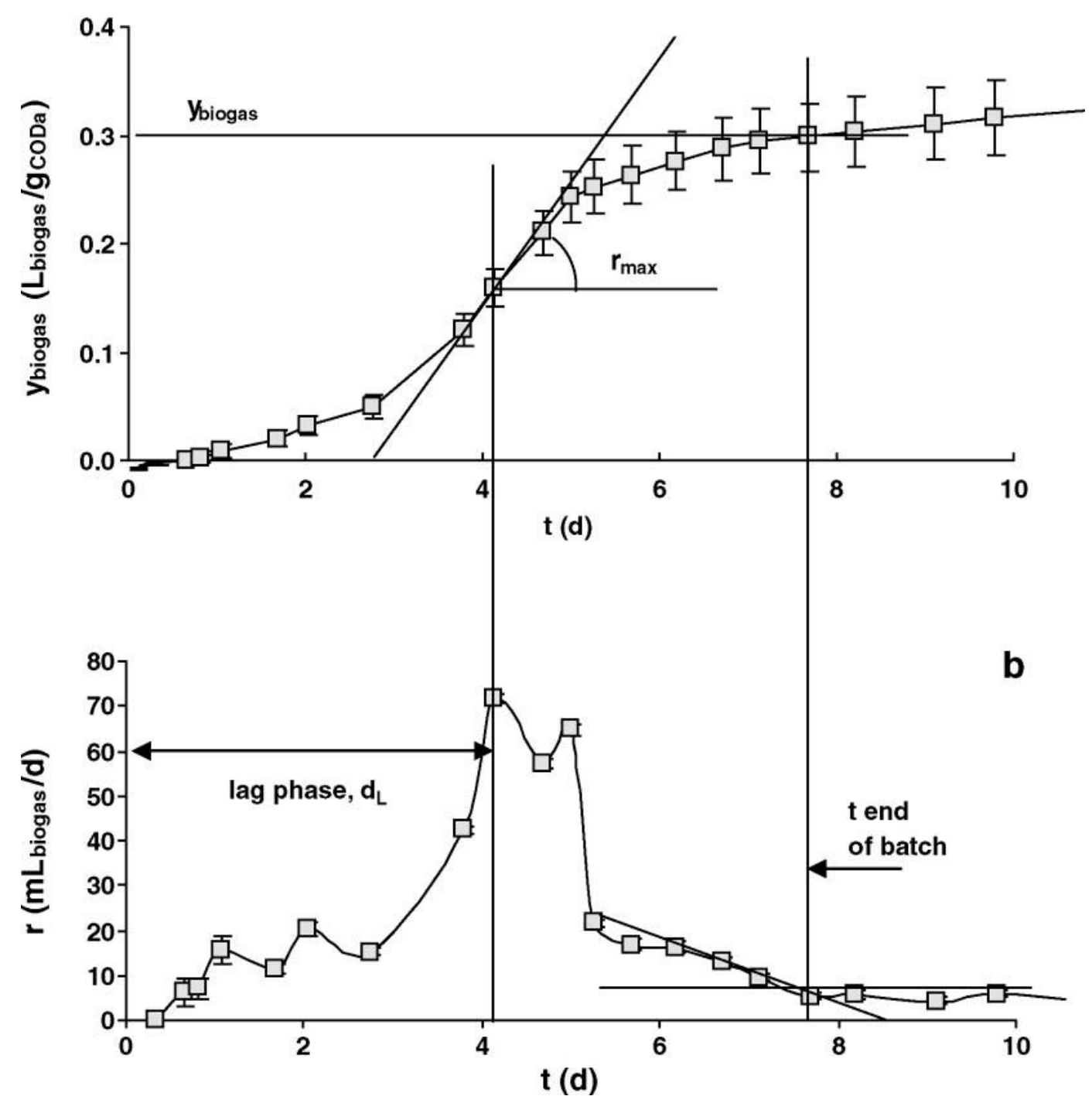

Figure 2. Methanization yield (or cumulative biogas production), $\mathrm{y}_{\text {biogas }}$ (a) and biogas production rate, $\mathrm{r}$ (b) versus time after addition of anhydrous milk fat at $0.5 \mathrm{~kg}_{\mathrm{COD}} / \mathrm{kg}$ of volatile suspended solids. The biogas production rate is obtained from derivation of cumulative biogas production. The time, $t$, end of batch is graphically determined on Figure $2 \mathrm{~b}$ when the biogas production rate (r) is constant and reaches the endogenous respiration level $\left(<5 \mathrm{~mL} / \mathrm{d}\right.$ ). The methanization yield ( $\mathrm{y}_{\text {biogas }}$ ) is determined on Figure $2 \mathrm{a}$ at $\mathrm{t}$ end of batch. The length of the lag phase $\left(\mathrm{d}_{\mathrm{L}}\right)$ is graphically determined on Figure $2 \mathrm{~b}$ when $\mathrm{r}$ reaches its maximum. The maximum biogas production rate $\left(\mathrm{r}_{\max }\right)$ is graphically determined on Figure 2a by drawing the tangent of the curve $y_{\text {biogas }}=f(t)$ after the lag phase.

\section{Experimental Design and Calculations}

Anaerobic degradation experiments were conducted in $250 \mathrm{~mL}$ (active volume) hermetical vessels shaken at $60 \mathrm{rpm}$ for 20 to $70 \mathrm{~d}$. Operating conditions were as follows: $35^{\circ} \mathrm{C} ; \mathrm{pH}$ not regulated and set at 7.2 ; acclimated anaerobic biomass $5 \mathrm{~kg}$ vss $/ \mathrm{m}^{3}$; substrate to biomass ratio 0.1 to $10 \mathrm{~kg}_{\mathrm{COD}} / \mathrm{kg}_{\mathrm{VSS}}$. The biogas production was evaluated by measuring the pressure increase in the vessel's atmosphere using a syringe.

Endogenous biogas production was determined on a vessel without any exogenous added COD and was subtracted from the total biogas production before calculations. Yield, maximum degradation rate, and length of lag phase before biogas production were determined as described in Figure 2. 
The biogas production or methanization yield ( $\mathbf{y}_{\text {biogas }}$, $\mathrm{m}_{\text {biogas }}^{3} / \mathrm{kg}_{\mathrm{CODa}}$; Figure 2a) was calculated as follows:

$$
\mathrm{y}_{\text {biogas }}=\frac{\mathrm{V}_{\text {biogas }}}{\mathrm{COD}_{\mathrm{a}}},
$$

where $\mathbf{V}_{\text {biogas }}=$ biogas volume produced during the batch experiment $\left(\mathrm{m}^{3}\right)$. The error on calculation was 1 to $20 \%$ depending on the frequency of measurements (0.5 to 5 per day) and precision (1 to $10 \%$ ).

Maximum biogas production rate $\left(\mathbf{r}_{\text {max }}, \mathrm{m}^{3}{ }_{\text {biogas }} / \mathrm{h} /\right.$ $\mathrm{kg}_{\mathrm{VSS}}$ ) was graphically determined as the tangent of the curve biogas production rate $(\mathbf{r}) \mathrm{r}=\mathrm{f}(\mathrm{t})$ at the inflection point (Figure 2a). The error on calculation was 10 to $55 \%$ depending on the frequency of measurements $(0.5$ to 5 per day) and precision (1 to $40 \%$ ).

The length of the lag phase before biogas production $\left(\mathbf{d}_{\mathrm{L}}\right)$ was graphically determined on the curve $\mathrm{r}=\mathrm{f}(\mathrm{t})$ as indicated in Figure 2b. The error in calculation was 10 to $30 \%$.

The composition of the biogas was determined at the end of anaerobic degradation experiments. Because of the regular biogas extractions by a syringe, this analysis represented only a fraction of the total biogas produced.

\section{Analyses}

Dry matter was measured by heating a 5-g sample at $105^{\circ} \mathrm{C}$ during $7 \mathrm{~h}$. Analyses were performed in duplicate. The error on calculation was $0.06 \%$. Ash content was determined by heating a 5 -g sample at $550^{\circ} \mathrm{C}$ for 3 $\mathrm{h}$. Analyses were performed in duplicate. The error on calculation was $0.06 \%$.

Suspended solids (SS) were determined on 20-mL samples after centrifugation at $3,000 \times g, 20^{\circ} \mathrm{C}$ for 20 min (Cryofuge M7000, Heraeus, Germany) and drying at $105^{\circ} \mathrm{C}$ overnight (NF T-90 105 2, AFNOR French Standard, 1997). The error on measurement was $2 \%$. Mineral suspended solids were obtained after drying the $\mathrm{SS}$ residue at $500^{\circ} \mathrm{C}$ for $5 \mathrm{~h}$. The error on measurement was $2 \%$. Volatile suspended solids corresponded to the difference between SS and mineral SS.

The COD was measured by Nanocolor Test $29 \mathrm{cu}-$ vettes and a PF 10 pocket filter photometer (Macherey Nagel kit, Düren, Germany). This method was correlated with the results given by NF T-90 101 AFNOR French standard (2001). Soluble COD was measured after sample centrifugation $\left(15,000 \times \mathrm{g}, 20^{\circ} \mathrm{C}, 5 \mathrm{~min}\right.$; accuracy $3 \%$ ). Fatty matter of thermized cream was measured by the Schmid-Bondzinsky-Ratzlaff method (V04-215, AFNOR French Standard, 1969).
The fatty acid nature (C2 to $\mathrm{C} 20)$ and concentration were determined by gas chromatography as described by Thierry et al. (2002) using a Varian CP 3800 GC FID; semi-capillary silica column BP21 SGE $25 \mathrm{~m} \times$ $0.53 \mathrm{~mm} \times 0.5 \mu \mathrm{m}$ (SGE, Courtaboeuf, France); carrier gas hydrogen, $28 \mathrm{kPa}$.

Biogas composition $\left(\mathrm{CO}_{2}, \mathrm{O}_{2}, \mathrm{~N}_{2}, \mathrm{H}_{2}\right.$, and $\left.\mathrm{CH}_{4}\right)$ was determined by gas chromatography (Varian 3400, Les Ulis, France). The individual gases were separated on a 2-packed column system (Haysep Q 80-100 $2 \mathrm{~m}$ and molecular sieve A $10 \mathrm{~m}$ ). Then, $0.5 \mathrm{~mL}$ of gas was injected at $100^{\circ} \mathrm{C}$; argon was the carrier gas at $280 \mathrm{kPa}$. Detection was performed with a thermal conductivity detector at $40^{\circ} \mathrm{C}$ with $74 \mathrm{~mA}$ catharometer current intensity. The error on measurement was $1 \%$.

\section{RESULTS AND DISCUSSION}

\section{Impact of Nature of Fat and Load on Performance of Anaerobic Degradation ( $y_{\text {biogas }}, r_{\max }, d_{L}$ )}

Comparison of 2 Fatty Substrates (Thermized Cream, AMF) with the Nonfatty Reference Substrate. Regardless of the load [ratio of the substrate concentration $\left(\mathbf{S}_{\mathbf{0}}\right)$ over the biomass concentration $(\mathbf{X})$ ], the skim milk, which corresponds to the nonfatty reference substrate, led to an asymptotical biogas production profile (Figure 3). In contrast, fat showed a sigmoid biogas production profile, except for the thermized cream at a load of $10 \mathrm{~kg}_{\mathrm{COD}} / \mathrm{kg}_{\mathrm{VSS}}$. In that case, the asymptotical biogas production profile, which characterized a sharp inhibition of methane production, was due to a too high load.

Compared with skim milk, fat altered the performance of the anaerobic degradation, regardless of its structure: the length of the lag phase before methanogenesis $\left(\mathrm{d}_{\mathrm{L}}\right)$ increased and the maximum biogas production rate $\left(\mathrm{r}_{\max }\right)$ decreased significantly (Table 1$)$.

The biogas production ( $\mathrm{y}_{\text {biogas }}$ ) could be considered as similar for the 3 substrates degraded with a load ranging from 0.1 to $2.0 \mathrm{~kg}_{\mathrm{COD}} / \mathrm{kg}_{\mathrm{vss}}$ (Table 1). However, for the 3 studied substrates, an increase in load up to 10 $\mathrm{kg}_{\mathrm{COD}} / \mathrm{kg}_{\mathrm{VSS}}$ led to a significant decrease in $\mathrm{y}_{\text {biogas }}$, much more pronounced for fat substrates.

Regardless of the nature of the substrate, actual biogas production was systematically lower than the theoretical production $\left[0.66 \mathrm{~L}_{\text {biogas }} / \mathrm{kg}_{\mathrm{CODa}}\left(35^{\circ} \mathrm{C}, 1 \mathrm{~atm}\right)\right.$ with biogas containing $60 \% \mathrm{CH}_{4}$, the proportion observed during acclimation; Figure 3]. A part of the COD was actually converted into biomass, and another part was not consumed (up to $90 \%$ at $\mathrm{S}_{0} / \mathrm{X}=10 \mathrm{~kg} \mathrm{COD}_{\mathrm{C}} / \mathrm{kg}_{\mathrm{VSS}}$, Table 1). At the end of the batch at $\mathrm{S}_{0} / \mathrm{X}=10 \mathrm{~kg}_{\mathrm{COD}} /$ $\mathrm{kg}_{\mathrm{VSS}}$, fat aggregation was observed: the SS concentra- 


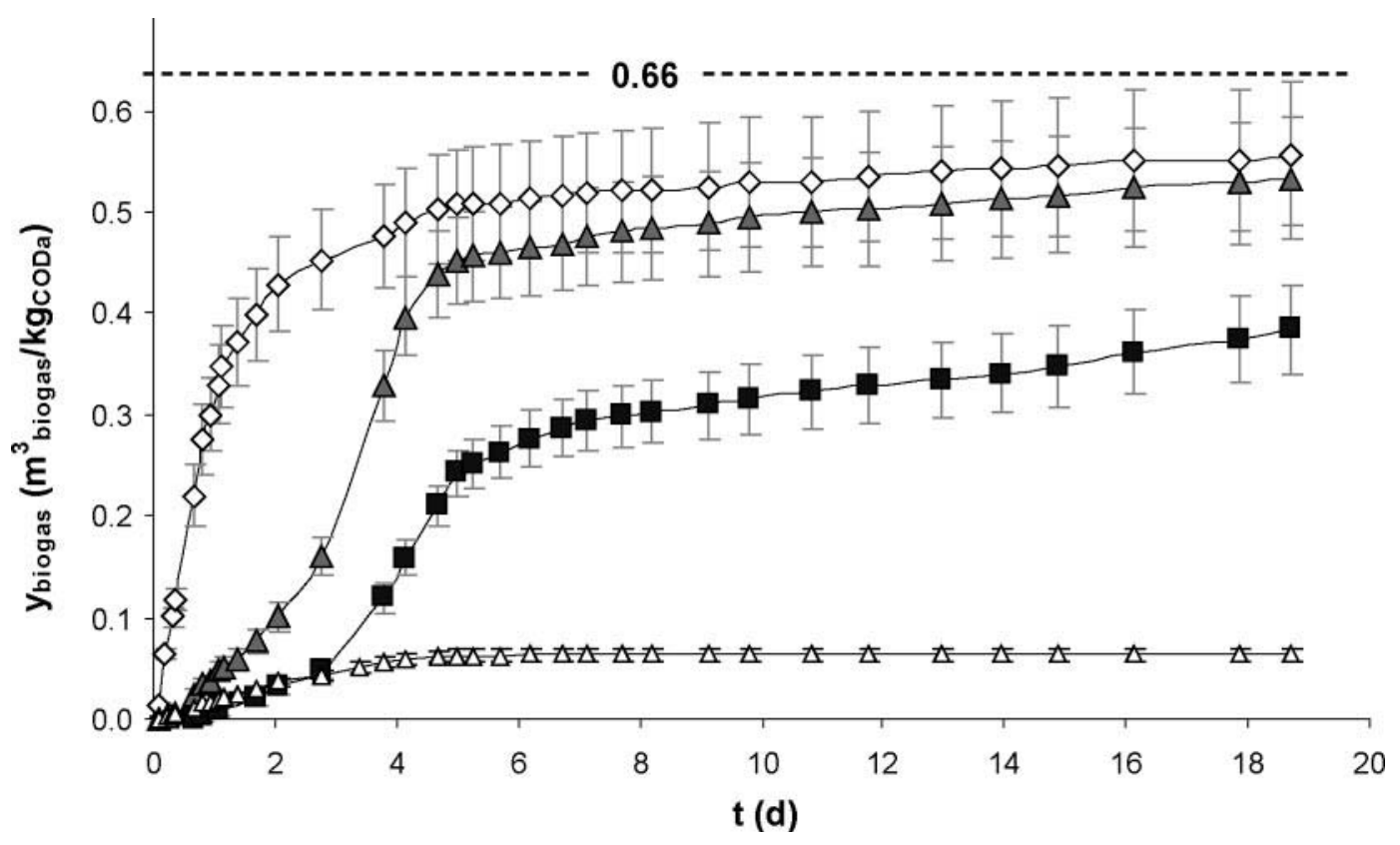

Figure 3. Examples of cumulative biogas production kinetics: Evolution of the biogas production yield, $\mathrm{y}_{\text {biogas }}$ in the course of time for different substrates (single experiment, endogenous biogas production was discounted): $\diamond=\operatorname{skim}$ milk; $\boldsymbol{\Delta}=\operatorname{cream} ; \boldsymbol{\square}=$ anhydrous milk fat $\left(\mathrm{S}_{0} / \mathrm{X}\right.$ $=0.5 \mathrm{~kg}$ CoD $\left./ \mathrm{kg}_{\mathrm{VSS}}\right) . \Delta=$ cream $\left(\mathrm{S}_{0} / \mathrm{X}=10 \mathrm{~kg}\right.$ CoD $\left./ \mathrm{kg}_{\mathrm{VSS}}\right) . \mathrm{S}_{0} / \mathrm{X}=$ load; $\mathrm{COD}_{\mathrm{a}}=$ added chemical oxygen demand; VSS $=$ volatile suspended solids -.---- = maximal theoretical yield $\left(35^{\circ} \mathrm{C}, 1 \mathrm{~atm}, 60 \% \mathrm{CH}_{4}\right.$ : similar composition as biogas composition during acclimation).

tion was significantly greater than at the beginning of the batch and the high organic content of SS (Table 2) showed that nondegraded fat, proteins, or both were directly implicated. At low load, it was impossible to quantify the nondegraded matter due to measurement precision. It could, however, explain the low value of $\mathrm{y}_{\text {biogas }}$, observed for AMF at $\mathrm{S}_{0} / \mathrm{X}=0.5 \mathrm{~kg}_{\mathrm{COD}} / \mathrm{kg}_{\mathrm{VSS}}$, and its high experimental variations observed for cream and $\mathrm{AMF}$ at $\mathrm{S}_{0} / \mathrm{X}=2 \mathrm{~g}_{\mathrm{COD}} / \mathrm{g}_{\mathrm{VSS}}$ (Table 1 ).

Biogas production from fatty substrates took place after a lag phase $\left(\mathrm{d}_{\mathrm{L}}\right)$, which lasted from 3 to $7 \mathrm{~d}$. No lag phase was observed during the methanization of components of skim milk (lactose, proteins; Table 1). The length of the lag phase was independent of the fat structure and was not correlated to the load (Table 1). The absence of relationship between lag phase and load seemed to contradict the results reported by Hanaki et al. (1981) and Vidal et al. (2000). However, the unique experiment performed by those authors does not clearly indicate whether the observed lag phase increases are significant or not: they actually did not evaluate the reproducibility between experiments, which is responsible in our work for the major part of the error.

The maximum biogas production rate $\left(\mathrm{r}_{\max }\right)$ was significantly lower with fatty substrates than with skim milk components: 2 to 5 times lower at a nonlimiting load (Table 1). The specific adsorption of organic matter (fat, proteins) to SS, more pronounced at high load
$\left(\mathrm{S}_{0} / \mathrm{X}=10 \mathrm{~kg}_{\mathrm{COD}} / \mathrm{kg}_{\mathrm{VSS}}, 26<\mathrm{S}_{0}<47 \mathrm{~kg}_{\mathrm{DM}} / \mathrm{m}^{3}\right)$, could explain this decrease in $r_{\max }$.

At low load, $\mathrm{S}_{0} / \mathrm{X} \leq 2 \mathrm{~kg}_{\mathrm{COD}} / \mathrm{kg}_{\mathrm{VSS}}\left(\mathrm{S}_{0} \leq 10 \mathrm{~kg}_{\mathrm{DM}} / \mathrm{m}^{3}\right)$, the adsorption of fat and proteins to biomass could not be quantified: the production of SS was small and could be mainly attributed to biomass production; the ratio VSS/SS at the end of the batch was not significantly different from the ratio measured in biomass at the beginning of the batch before the addition of substrate $\left(0.64 \pm 0.02 \mathrm{~kg} \mathrm{VsS}_{\mathrm{VS}} / \mathrm{kg}_{\mathrm{SS}}\right)$. However, at a greater load $\left(\mathrm{S}_{0} / \mathrm{X}=10 \mathrm{~kg}_{\mathrm{COD}} / \mathrm{kg}_{\mathrm{VSS}}, 26<\mathrm{S}_{0}<47 \mathrm{~kg}_{\mathrm{DM}} / \mathrm{m}^{3}\right)$, SS accumulation was greater with the 2 fatty substrates $(0.53$ $\mathrm{kg}_{\mathrm{SS}} / \mathrm{kg}_{\mathrm{DM}}$ for added cream; $0.43 \mathrm{kgSS} / \mathrm{kg}_{\mathrm{DM}}$ for added AMF) than with skim milk $\left(0.09 \mathrm{~kg}_{\mathrm{SS}} / \mathrm{kg}_{\mathrm{DM}}\right)$. The ratio VSS/SS increased significantly during the batch operation, indicating an adsorption of the added substrate (protein and/or fat) on SS.

Fat methanization clearly pointed out the fact that the kinetics limitations observed with complex milk substrates could be mainly attributed to fat. Moreover, it is clear enough that the conversion of fat globules into triglycerides (Figure 1) is not a limiting step because the performance obtained with cream or with triglycerides suspensions was similar.

Dysfunctions of Anaerobic Digestion at High Load. At high load $\left(\mathrm{S}_{0} / \mathrm{X}=10 \mathrm{~kg} \mathrm{COD}_{\mathrm{CO}} / \mathrm{kg}_{\mathrm{vsS}}\right)$, with or without fat, some dysfunctions of anaerobic digestion were observed. At the end of skim milk methanization 
Table 1. Methanization performance of fatty and nonfatty substrates ${ }^{1}$

\begin{tabular}{|c|c|c|c|c|c|c|c|c|c|c|c|}
\hline \multirow[b]{3}{*}{ Substrate } & \multirow{3}{*}{$\begin{array}{c}\mathrm{S}_{0} / \mathrm{X} \\
\left(\mathrm{kg}_{\mathrm{COD}} / \mathrm{kg}_{\mathrm{VSS}}\right)\end{array}$} & & & \multicolumn{3}{|c|}{ Consumed COD } & & & \multicolumn{2}{|c|}{$d_{L}$} & \multirow[b]{3}{*}{$\mathrm{n}$} \\
\hline & & \multicolumn{2}{|c|}{$\mathrm{y}_{\text {biogas }}\left(\mathrm{m}_{\text {biogas }}^{3} / \mathrm{kg}_{\mathrm{CODa}}\right)$} & \multicolumn{2}{|c|}{$\% \mathrm{COD}_{\mathrm{a}}$} & & \multicolumn{2}{|c|}{$\left(10^{-3} \mathrm{~m}_{\text {biogas }}^{3} / \mathrm{h} / \mathrm{kg}_{\mathrm{VSS}}\right)$} & \multicolumn{2}{|c|}{ Day } & \\
\hline & & Mean & $\mathrm{SD}$ & Mean & $\mathrm{SD}$ & & Mean & $\mathrm{SD}$ & Mean & SD & \\
\hline Skim milk & 0.10 & 0.44 & 0.08 & 140 & 63 & (1) & 3 & 1 & 0.1 & 0.1 & 1 \\
\hline Skim milk & 0.50 & 0.51 & 0.04 & 96 & 19 & & 9 & 2 & 0.2 & 0.2 & 1 \\
\hline Skim milk & 2.0 & 0.54 & 0.05 & 86 & 6 & & 21 & 5 & 0.3 & 0.1 & 3 \\
\hline Skim milk & 10 & 0.23 & 0.01 & 10 & 37 & (2) & 76 & 12 & 0.8 & 0.1 & 1 \\
\hline AMF & 0.10 & 0.46 & 0.09 & 71 & 128 & (1) & 0.6 & 0.1 & 4.2 & 0.4 & 1 \\
\hline $\mathrm{AMF}$ & 0.50 & 0.41 & 0.03 & 72 & 26 & & 2.4 & 0.3 & 4.0 & 0.7 & 2 \\
\hline $\mathrm{AMF}$ & 2.0 & 0.49 & 0.09 & 72 & 7 & & 6 & 3 & 7.1 & 2 & 3 \\
\hline $\mathrm{AMF}$ & 10 & 0.09 & 0.01 & 13 & 26 & (2) & 9 & 2 & 5.3 & 0.4 & 1 \\
\hline Thermized cream & 0.11 & 0.48 & 0.08 & 80 & 100 & (1) & 0.8 & 0.3 & 3.1 & 1.1 & 1 \\
\hline Thermized cream & 0.50 & 0.48 & 0.04 & 76 & 24 & & 3.6 & 0.6 & 4.2 & 0.4 & 1 \\
\hline Thermized cream & 2.0 & 0.48 & 0.07 & 80 & 6 & & 7 & 3 & 5.7 & 1 & 3 \\
\hline Thermized cream & 10 & 0.06 & 0.00 & 30 & 10 & (2) & 8 & 2 & ND & & 1 \\
\hline Hydrolyzed AMF & 2.0 & 0.50 & 0.06 & 90 & 6 & & 5 & 1 & 17.4 & 0.5 & 2 \\
\hline Hydrolyzed cream & 2.0 & 0.55 & 0.07 & 97 & 5 & & 6 & 1 & 17.4 & 0.5 & 2 \\
\hline FFA C18:1 & 0.8 & 0.44 & 0.08 & $\mathrm{ND}^{(3)}$ & & & 0.6 & 0.1 & 27 & 3 & 2 \\
\hline FFA C16:0 & 1.2 & 0.20 & 0.01 & $\mathrm{ND}^{(3)}$ & & & 0.5 & 0.2 & 0 & 0 & 2 \\
\hline FFA C18:1+C16:0 & $0.8+1.2$ & 0.42 & 0.06 & $\mathrm{ND}^{(3)}$ & & & 1.1 & 0.1 & 27 & 3 & 2 \\
\hline
\end{tabular}

${ }^{1}$ Operating conditions: VSS $(t=0)=5.0 \mathrm{~kg} / \mathrm{m}^{3} ; \mathrm{VSS} / \mathrm{SS}=0.64 ;{ }^{(1)}$ high error due to low load; ${ }^{(2)}$ high error due to heterogeneity of liquor; ${ }^{(3)}$ residual COD of FFA could not be determined with experimental methods used; $\mathrm{AMF}=$ anhydrous milk fat; $\mathrm{COD}=$ chemical oxygen demand; $\mathrm{COD}_{\mathrm{a}}=\mathrm{added}_{\mathrm{COD}}$ C18:1 = oleate; $\mathrm{C} 16: 0=$ palmitate; $\mathrm{d}_{\mathrm{L}}=$ lag phase; $\mathrm{S}_{0} / \mathrm{X}=$ load (substrate concentration/biomass concentration); $\mathrm{SS}=$ suspended solids; VSS = volatile suspended solids; $\mathrm{y}_{\text {biogas }}=$ methanization yield; $\mathrm{ND}=$ not determined; $\mathrm{n}=$ number of replicates; and $\mathrm{SD}=$ error on calculation if one replicate or maximum between error on calculation and standard deviations if more than one replicate. 
Table 2. Methanization performance of fatty and nonfatty substrates ${ }^{1}$

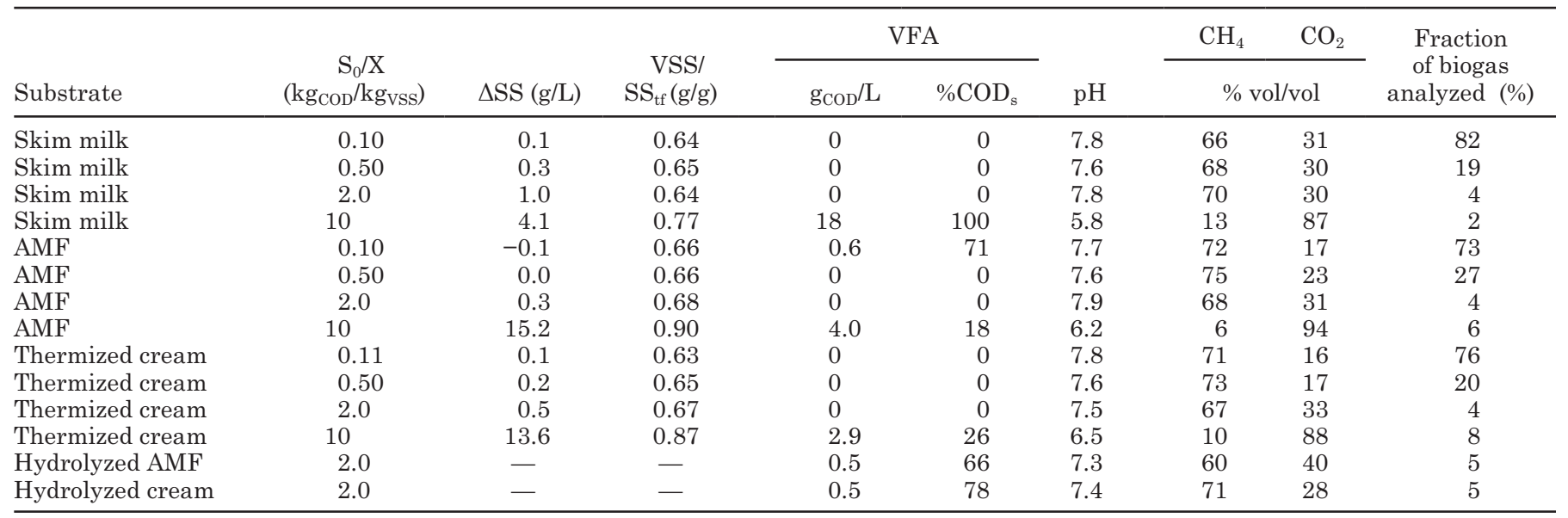

${ }^{1}$ Operating conditions: VSS $(t=0)=5.0 \mathrm{~kg} / \mathrm{m}^{3} ; \mathrm{VSS} / \mathrm{SS}=0.64 ; \Delta \mathrm{SS}=$ variation of suspended solids during the experiment; $\mathrm{SScf}=$ suspended solids at the end of the experiment; VSS = volatile suspended solids; $\mathrm{S}_{0} / \mathrm{X}=$ load (substrate concentration/biomass concentration); COD = chemical oxygen demand; $\mathrm{COD}_{\mathrm{S}}=$ soluble $\mathrm{COD} ; \mathrm{AMF}=$ anhydrous milk fat.

under high load $\left(\mathrm{S}_{0} / \mathrm{X}=10 \mathrm{~kg}_{\mathrm{COD}} / \mathrm{kg}_{\mathrm{VSS}}\right)$, a low proportion of added skim milk (9\% DM) was aggregated with suspended solids. The soluble COD in the reactor ( $36 \%$ of the added COD) was totally constituted by low molecular weight FFA (Table 3), the concentrations of which reached $11.1 \mathrm{~kg} / \mathrm{m}^{3}$ with $5.2 \mathrm{~kg} / \mathrm{m}^{3}$ of butyric acid at the end of the experiment (Table 3). Moreover, the proportion of methane (13\%) in the biogas was low compared with proportions found with lower load (66 to $73 \%$ at $\mathrm{S}_{0} / \mathrm{X} \leq 2 \mathrm{~kg}_{\mathrm{COD}} / \mathrm{kg}_{\mathrm{vsS}}$, Table 2 ).

The concentration of VFA, which are the main intermediate compounds in the conversion of organic substrate to biogas, can help understanding which conversion step is the most limiting. In particular, during the experiment with high load of skim milk, as the totality of the soluble COD is constituted of VFA, it may be assumed that the activity of hydrolytic and acidogenic bacteria (which are responsible for the conversion of organic molecules to VFA) were less affected than bacteria responsible for the degradation of VFA. More precisely, the acetogenic phase showed a dysfunction because the substrates of this degradation step (VFA with 3 to 5 carbons) were present at high quantity. These observations confirmed the work of Vidal et al. (2000), who also reported a decrease in biogas production yield in batch with a similar load (10 $\mathrm{kg}_{\mathrm{COD}} / \mathrm{kg}_{\mathrm{vsS}}$ ) associated with VFA accumulation: 4.0 $\mathrm{kg}_{\mathrm{COD}} / \mathrm{m}^{3}$ of butyric acid for a total VFA concentration of $6.5 \mathrm{~kg}_{\mathrm{COD}} / \mathrm{m}^{3}$.

The dysfunction of acetogenesis, which results in a VFA accumulation, could originate from an alteration of the activity of the hydrogenotrophic methanogens, which are responsible for the production of $\mathrm{CH}_{4}$ from $\mathrm{H}_{2}$ and $\mathrm{CO}_{2}$. A decrease in the activity of hydrogenotrophic methanogens would actually lead to a rapid accumulation of $\mathrm{H}_{2}$. Hydrogen gas accumulation further leads to VFA accumulation because the degradation of propionate and butyrate to acetate is, from a thermodynamic point of view, only possible at $\mathrm{H}_{2}$ partial pressure lower than $10^{-4}$ and $10^{-3} \mathrm{~atm}$, respectively (Moletta, 2006). However, the sensibility of our biogas analysis method did not allow measurement of such low partial pres-

Table 3. Concentration of volatile fatty acids at the end of anaerobic degradation ${ }^{1}$

\begin{tabular}{|c|c|c|c|c|c|c|c|c|}
\hline Substrate & $\begin{array}{c}\mathrm{S}_{0} / \mathrm{X} \\
\left(\mathrm{kg}_{\mathrm{COD}} / \mathrm{kg}_{\mathrm{VSS}}\right) \\
\end{array}$ & $\begin{array}{l}\text { Acetate } \\
\left(\mathrm{kg} / \mathrm{m}^{3}\right)\end{array}$ & $\begin{array}{l}\text { Propionate } \\
\left(\mathrm{kg} / \mathrm{m}^{3}\right)\end{array}$ & $\begin{array}{l}\text { Isobutyrate } \\
\left(\mathrm{kg} / \mathrm{m}^{3}\right)\end{array}$ & $\begin{array}{c}\text { Butyrate } \\
\left(\mathrm{kg} / \mathrm{m}^{3}\right)\end{array}$ & $\begin{array}{l}\text { Isovalerate } \\
\left(\mathrm{kg} / \mathrm{m}^{3}\right)\end{array}$ & \multicolumn{2}{|c|}{ Total } \\
\hline $\mathrm{AMF}$ & 10 & 0.53 & 1.40 & 0.04 & 0.65 & 0.07 & 2.7 & 18 \\
\hline Thermized cream & 10 & 0.47 & 0.89 & 0.09 & 0.36 & 0.12 & 1.9 & 26 \\
\hline Skim milk & 10 & 3.70 & 0.47 & 0.60 & 5.20 & 1.10 & 11.1 & 100 \\
\hline
\end{tabular}

${ }^{1}$ Operating conditions: $\operatorname{VSS}(t=0)=5.0 \mathrm{~kg} / \mathrm{m}^{3} ; \mathrm{VSS} / \mathrm{SS}=0.64 . \mathrm{AMF}=$ anhydrous milk fat; $\mathrm{COD}=$ chemical oxygen demand; $\mathrm{S}_{0} / \mathrm{X}=$ load $(\mathrm{sub}-$ strate concentration/biomass concentration); VSS = volatile suspended solids. 


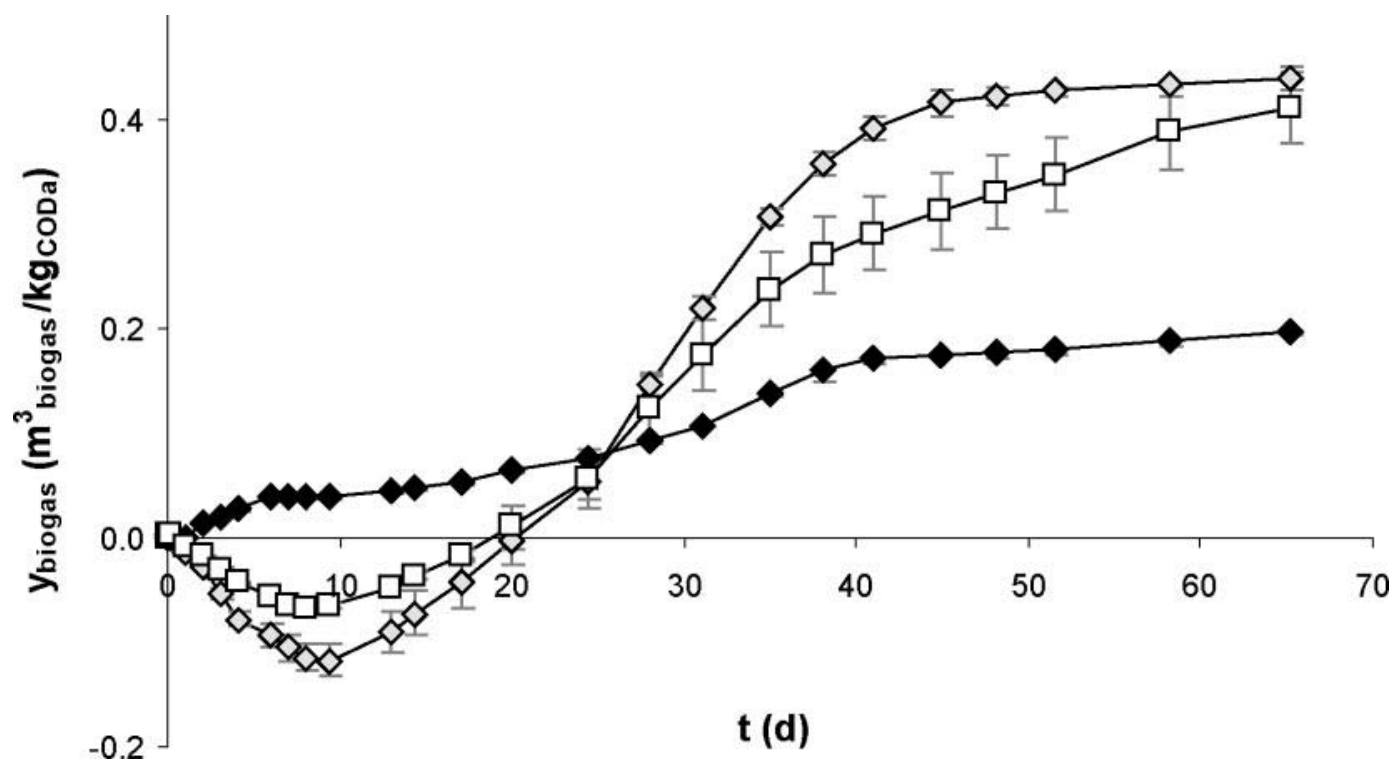

Figure 4. Yield of methanization ( $\mathrm{y}_{\text {biogas }}$ ) from FFA. Volatile suspended solids (VSS, $\left.t=0\right)=5 \mathrm{~kg} / \mathrm{m}^{3}$; means and standard deviation

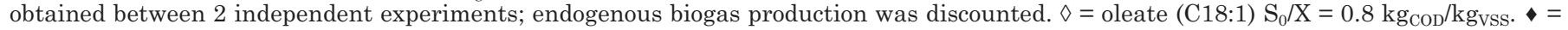
palmitate $(\mathrm{C} 16: 0) \mathrm{S}_{0} / \mathrm{X}=1.2 \mathrm{~kg}_{\mathrm{COD}} / \mathrm{kg}_{\mathrm{VsS}} \cdot \square=$ oleate + palmitate $\mathrm{S}_{0} / \mathrm{X}=0.8+1.2 \mathrm{~kg}_{\mathrm{COD}} / \mathrm{kg}_{\mathrm{VsS}} . \mathrm{COD}=$ chemical oxygen demand; COD $=$ added COD.

sures of $\mathrm{H}_{2}$. It was therefore not possible to determine if the presence of VFA at the end of the batch was due to an inhibition of hydrogenotrophic $\left(\mathrm{H}_{2}\right)$ or acetoclastic $\left(\mathrm{CH}_{4}\right)$ bacteria.

The activity of acetoclastic methanogens, responsible for $70 \%$ of $\mathrm{CH}_{4}$ production (Moletta, 2006), also showed dysfunction at high load of skim milk, as shown by the low proportion of methane in the biogas and the high concentration of acetic acid $\left(3.7 \mathrm{~kg} / \mathrm{m}^{3}\right)$ at the end of the batch (Table 3). Accumulation of dissolved free ammoniac $\left(\mathrm{NH}_{3}\right)$ could not explain this dysfunction because at a load $\left(10 \mathrm{~kg}_{\mathrm{COD}} / \mathrm{kg}_{\mathrm{VSS}}\right)$, the added nitrogen represented only $2 \mathrm{~kg}_{\mathrm{N}} / \mathrm{m}^{3}$. If totally converted into ammonia, this amount would represent less than $3 \mathrm{mg}_{\mathrm{N}-\mathrm{NH}_{3}} / \mathrm{m}^{3}$ at $\mathrm{pH}$ 5.8. This value is very low compared with range of 25 to $140 \mathrm{mg}_{\mathrm{N}-\mathrm{NH} 3} / \mathrm{L}$ reported to inhibit the mesophilic methanization (Omil et al., 1995). In contrast, the accumulation of VFA $\left(18 \mathrm{~kg}_{\mathrm{COD}} / \mathrm{m}^{3}\right)$ due to a rapid hydrolysis/acidogenesis $\left(76 \pm 12 \mathrm{~L}_{\text {biogas }} / \mathrm{h} / \mathrm{kg}_{\mathrm{vss}}\right.$, Table 1) could explain the dysfunction of acetoclastic methanogens. The nonionized form of VFA freely diffuses through the membrane of the bacteria, accumulates in the cells, and induces methanogenesis inhibition when its concentration reaches $25 \mathrm{mEq} / \mathrm{L}\left(1.6 \mathrm{~kg} \mathrm{COD} / \mathrm{m}^{3} ; \mathrm{P}\right.$. Boulenger, Society P. Boulenger, Le Chesnay, France; personal communication). At pH 5.8 (Table 2), about $90 \%$ of VFA $\left(18 \mathrm{~kg}_{\mathrm{COD}} / \mathrm{m}^{3}\right)$ being in molecular form $\left(\mathrm{pK}_{a}\right.$ $=6.5$ to 7.0 ), the inhibiting concentration in molecular VFA was largely reached.
In the presence of fat, the methane proportion in the biogas was low for the highest load studied (6 to 10\%, Table 2) and the accumulation of VFA in the liquor was lower than that measured at the end of the skim milk methanization $\left(2.7\right.$ and $1.9 \mathrm{~kg} / \mathrm{m}^{3}$ for AMF and cream respectively, Table 3); this was probably due to a low acidification rate of fat compared with that obtained with simple carbohydrates like lactose (Vidal et al., 2000). In contrast of what was observed at the end of skim milk methanization batch, the VFA represented only a small part of the soluble COD (18\% with AMF and $26 \%$ with cream, Table 3 ), and a large part of the added organic matter (43 to $53 \% \mathrm{DM}$ ) was fixed to the suspended solids. These elements, together with the absence of VFA at $\mathrm{S}_{0} / \mathrm{X}<10 \mathrm{~kg}_{\mathrm{COD}} / \mathrm{kg}_{\mathrm{VSS}}$, indicated that inhibition due to milk fat had major consequences on microbial processes before the acetogenesis, unlike inhibition due to high substrate load, which affected mainly acetogenesis.

The alteration of one or both of the first 2 steps of anaerobic degradation (hydrolysis and acidogenesis) could explain the lag phase before biogas production and the low biogas production rate observed under all studied loads. The mechanisms are partially elucidated (Komatsu et al., 1991; Petruy and Lettinga, 1997) and are presented in Figure 1.

Therefore, it seems that the low performance of the biogas production under high load of skim milk could be attributed to a dysfunction of the methanogenic ar- 


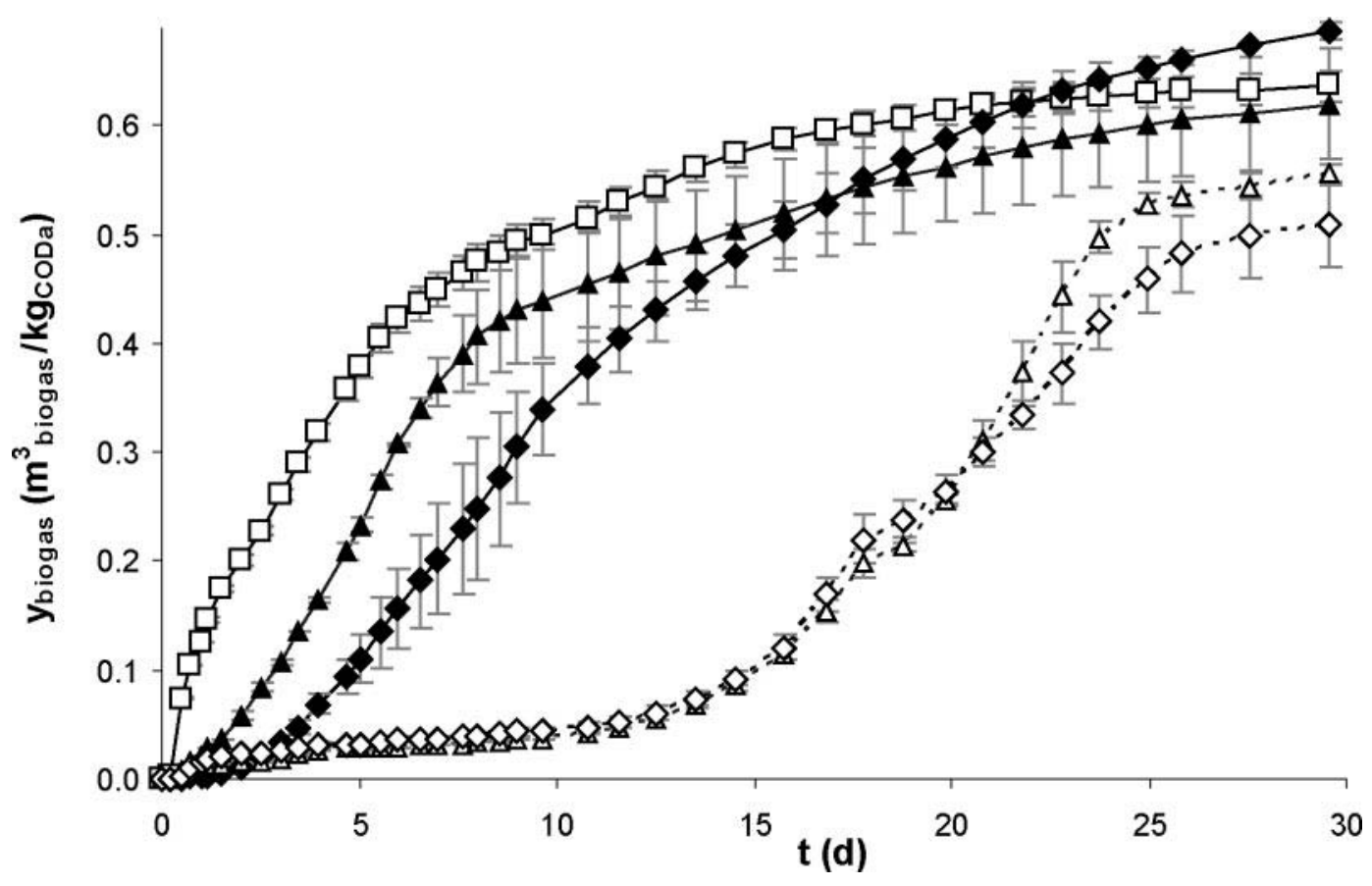

Figure 5. Yield of methanization ( $\mathrm{y}_{\text {biogas }}$ ) from skim milk, hydrolyzed, and nonhydrolyzed fat. $\mathrm{S}_{0}=2 \mathrm{~kg}$ CoD $/ \mathrm{kg}_{\mathrm{VSS}}$; volatile suspended solids $(\mathrm{VSS}, t=0)=5 \mathrm{~kg} / \mathrm{m}^{3}$; means and standard deviation between 2 independent experiments. See text for operating conditions. $\square=$ skim milk; $\boldsymbol{\Delta}=$ thermized cream; $\downarrow$ anhydrous milk fat, AMF; $\Delta=$ hydrolyzed cream; $\diamond=$ hydrolyzed $\mathrm{AMF} . \mathrm{COD}=$ chemical oxygen demand; $\mathrm{COD}$ a $=$ added COD.

chaea due to a high concentration of VFA, although, at high fat load, the performance is mainly limited by the hydrolysis and acidogenesis.

\section{Influence of Fat and FFA (C16:0 and C18:1) Hydrolysis on Biogas Production Performance}

To show and understand the mechanisms that rule the limiting effect of hydrolysis on biogas production, prehydrolyzed milk fat and individual FFA were methanized. The 2 major compounds generated by the fat hydrolysis, oleic and palmitic acids, were therefore methanized at concentrations close to that of unsaturated and saturated fatty acids contained in hydrolyzed fat submitted to methanization $\left(\mathrm{S}_{0} / \mathrm{X}=2 \mathrm{~kg}_{\mathrm{COD}} / \mathrm{kg}_{\mathrm{VSS}}\right)$.

$\boldsymbol{F F A}$. The profiles of gas production from $\mathrm{C} 18: 1$ and C16:0 are given in Figure 4. The C18:1 and C16:0 loads were similar to that of unsaturated and saturated FFA, respectively, obtained from anaerobic fat degradation at a total load of $2 \mathrm{~kg}_{\mathrm{COD}} / \mathrm{kg}_{\mathrm{VSs}}$. The values of $\mathrm{y}_{\text {biogas }}, \mathrm{d}_{\mathrm{L}}$, and $\mathrm{r}_{\max }$ are presented in Table 1. Between d 0 and 20 (Figure 4), biogas production yield ( $\mathbf{y}_{\text {biogas }}$ ) was negative because the endogenous biogas production (measured in a reference vessel with no added exogenous COD) was greater than that observed with the fatty acids. Biogas production relative to the added exogenous COD was actually calculated by subtracting the endogenous gas production from the total production (measured when exogenous COD was present).

Biogas production yield with $\mathrm{C} 18: 1$ and the mixture C16:0 + C18:1 was not significantly different from that obtained with skim milk or hydrolyzed fat (Table 1), whereas that obtained with $\mathrm{C} 16: 0$ alone was as low as $0.2 \mathrm{~m}^{3}{ }_{\text {biogas }} / \mathrm{kg}_{\mathrm{CODa}}$. This difference could be a consequence of a beneficial synergistic effect of the 2 compounds. Nevertheless, such an effect is not reported for the anaerobic degradation of either C18:1 or a mixture of 10 FFA (half of them being unsaturated FFA; Hanaki et al., 1981).

The maximal rate of biogas production $\left(\mathrm{r}_{\max }\right)$ from C16:0 and C18:1 was difficult to compare because the methanized loads were different. However, knowing that in the range of studied load ( 0.1 to $2 \mathrm{~kg}_{\mathrm{COD}} / \mathrm{kg}_{\mathrm{VSS}}$ ), $r_{\max }$ increased when load increased (Table 1), the results allow to state that on the one hand, the biogas production rate from these FFA was 20 to 40 times smaller than that of skim milk, and on the other hand, $r_{\max }$ $(\mathrm{C} 16: 0)<\mathrm{r}_{\max }(\mathrm{C} 18: 1)<\mathrm{r}_{\max }$ (AMF, cream). The experiments were conducted below the rate limiting substrate load, as shown by the fact that $\mathrm{r}_{\max }(\mathrm{C} 18: 1)+\mathrm{r}_{\max }(\mathrm{C} 16: 0)$ $=r_{\max }(\mathrm{C} 18: 1+\mathrm{C} 16: 0)$ (Table 1). Therefore, the small $\mathrm{r}_{\max }$ measured can really be attributed to the actual nature of the acids and not to a too high load. Pereira et al. (2005) have shown that palmitic acid (C16:0) is 
the main LCFA that accumulates onto the anaerobic sludge when oleic $(\mathrm{C} 18: 1)$ or palmitic $(\mathrm{C} 16: 0)$ acid is fed to an expanded granular sludge bed reactor. But the way C16:0 accumulates was different in C18:1 and in $\mathrm{C} 16: 0$ fed reactor. When C16:0 is fed to anaerobic biomass, it mainly precipitates in white spots, probably because of its lower solubility (Lefebvre et al., 1998), which reduces its accessibility and hence the rate of its degradation (Pereira et al., 2005).

Moreover, the biogas production from C18:1 and of the mixture $\mathrm{C} 16: 0+\mathrm{C} 18: 1$ both revealed a lag phase $\left(\mathrm{d}_{\mathrm{L}} ; 27 \pm 3 \mathrm{~d}\right)$ before gas started to be produced, whereas with $\mathrm{C} 16: 0$ alone gas production was much more constant during the whole experiment (Figure 4).

The results showed that the lag phase observed during the anaerobic degradation of cream and AMF could be due to the presence of FFA and more particularly to unsaturated fatty acids because no latent period was observed with the saturated FFA. More precisely, the lag phase can be attributed to the actual nature of unsaturated FFA. Indeed, when oleic acid, which represents the major part of milk fat unsaturated fatty acid, is fed to an anaerobic digester, the sludge becomes actually "encapsulated" by a LCFA layer, mainly composed of palmitic acid, an intermediate of the C18:1 degradation (Alves et al., 2001; Pereira et al., 2002). Unlike precipitation of $\mathrm{C} 16: 0$ when $\mathrm{C} 16: 0$ is fed to anaerobic biomass, adsorption of $\mathrm{C} 16: 0$ to the biomass when $\mathrm{C} 18: 1$ is fed does not reduce its rate of degradation but creates a physical barrier that inhibits the transfer of substrate and products, inducing a delay on the initial methane production (Pereira et al., 2005).

Furthermore, the negative gas production (Figure 4) shows that this inhibition not only affects the transfer of fed substrates (i.e., C16:0, C18:1) but also the transfer of endogenous COD, and, as a matter of fact, its degradation.

Hydrolyzed Fat. The pretreatment of fat (cream, AMF) through enzymatic hydrolysis generated an increase (2.5 to 3 times) of the lag phase before the biogas production step without significantly modifying $\mathrm{r}_{\max }$ and $\mathrm{y}_{\text {biogas }}$ (Table 1, Figure 5). The lag phase with the hydrolyzed fat (17 d, Figure 5) was significantly shorter than that observed in the presence of C18:1 (around $27 \mathrm{~d}$ ).

The delay imposed by unsaturated FFA in the biogas production explained the consequences observed for fat hydrolysis on the methanization performance. The lag phase for the hydrolyzed fat, longer than for raw fat, may be explained by an input at $t_{0}$ of inhibiting compounds (mainly C18:1) at high concentration. With raw fat, the effect of these inhibiting compounds was attenuated because the unsaturated FFA were continuously released by the in situ biological hydro- lysis, which was slow due to fat low solubility (Petruy and Lettinga, 1997). The initial low solubility of fat therefore enhanced the stability of its own anaerobic degradation although it constitutes a physical limit of this degradation.

The applied loads of C18:1 and C16:0 were chosen similar to that of unsaturated and saturated fatty acids, respectively, for the experiment of hydrolyzed AMF methanization, as a consequence of which similar values for $r_{\max }$ and $d_{L}$ were expected. The hydrolyzed fat showed better performance (shorter $d_{L}$, higher $r_{\max }$ after latency) than individual FFA.

According to Rinzema et al. (1994), this is likely to be due to the growth of a small number of methanogenic archaea, which have survived the toxicity of the fatty acids and have grown on noninhibitory FFA. Indeed, Rinzema et al. (1994) showed that the toxicity of C10:0 toward acetoclastic methanogens is almost irreversible and that the recovery of methane production after the lag phase can be described as an exponential growth of a small number of survivors. The acetoclastic methanogens cannot adapt to FFA (increase in the threshold of sensitivity) after a lethal dose of FFA or after a prolonged acclimation under nontoxic FFA concentrations. However, the growth after a lethal FFA dose was faster (thus, shorter lag phase) when the biomass was first in prolonged contact with small FFA concentration. As a result, following assumption of Rinzema et al. (1994), by contributing to the acceleration of the growth of the survivors, the presence of noninhibiting compounds (in particular short chain fatty acids) in the hydrolyzed fat would be liable to shorten $d_{L}$ and increase $r_{\max }$ of hydrolyzed fat as compared with individual fatty acids.

More recent work concluded the absence of biotoxicity of the long-chain FFA (Pereira et al., 2004). The apparent toxicity was explained by the "encapsulation" of biomass by unsaturated LCFA that prevents substrates and product transfer without affecting biomass activity (Pereira et al., 2005).

Fat prehydrolysis (enzymatic or other), which increased the solubility of fat by converting it to FFA and monoglycerides with surfactant properties (Petruy and Lettinga, 1997; Cammarota et al., 2001), yielded an overproduction of unsaturated FFA, which inhibits the methanization even though it repels the physical limits of methanization. On the opposite, a slow fat hydrolysis limits the accumulation of VFA (1.9 to 2.7 $\left.\mathrm{kg} / \mathrm{m}^{3}\right)$ generated by a high substrate load $\left(10 \mathrm{~kg}_{\mathrm{COD}} /\right.$ $\left.\mathrm{kg}_{\text {VSS }}\right)$ as compared with a nonfatty substrate $(11 \mathrm{~kg} /$ $\mathrm{m}^{3}$ ). According to Vidal et al. (2000), this slow hydrolysis could even favor, from a kinetic point of view, the anaerobic degradation of whole milk as compared with skim milk, in conditions of high load $\left(10 \mathrm{~kg} \mathrm{COD} / \mathrm{kg}_{\mathrm{VSS}}\right)$ where the methanogenesis is blocked by an inhibiting 
FFA concentration. Nonetheless, it is not recommended to operate an anaerobic degradation in these instable methanogenic conditions.

\section{Means Contributing to Reducing the Inhibitory Effects of Anaerobic Degradation}

To reduce the inhibitory effects of the unsaturated FFA toward substrate transfers, its proportion in milk fat must be reduced before they get into contact with the anaerobic biomass. This means that to degrade fat, the unsaturated FFA concentration must be maintained as low as possible and, if possible, unsaturated FFA must be saturated.

The inhibiting power of FFA may be reduced by limiting the accessibility of FFA to the biomass: adsorption onto active carbon (Mensah and Forster, 2003) or precipitation with calcium chloride (Hanaki et al., 1981) can be accomplished, but it artificially reduces FFA bioassimilation. Moreover, these operations are inefficient when biomass has been into contact with subinhibiting concentrations of FFA for several hours (Hanaki et al., 1981).

A predigestion may be proposed to reduce the toxicity of the unsaturated FFA. Indeed, an anaerobic preacidification ( $\mathrm{pH} 8$, hydraulic residence time $>8 \mathrm{~h}$ ) that achieves a partial conversion of oleate to palmitate (15 to $25 \%$ ) allows the reduction of the whole duration of its conversion to methane by $30 \%$ as compared with a 1-step anaerobic digestion (Komatsu et al., 1991). Such a pretreatment, which was shown to be efficient with a simple and single substrate, could also be operated in aerobic conditions for milk fat. Indeed, on the one hand, the first steps of degradation are similar (hydrolysis, saturation, B-oxidation) in aerobic and anaerobic conditions, and on the other hand, the degradation rate of unsaturated fatty acids by an activated sludge is faster than that of saturated fatty acids. This is particularly true for the major 2 milk fatty acids: at identical concentration, oleate is degraded twice as fast as palmitate (Lefebvre et al., 1998).

A limited biological aerobic (Sage, 2005) or anaerobic pretreatment, possibly combined with the action of a lipase, could result in improvements in milk fat anaerobic digestion performance. The efficiency of an aerobic pretreatment combined with the action of Penicillium restrictum lipase on aerobic and anaerobic biological treatment of fatty wastewaters was quantified by Cammarota and Freire (2006).

\section{CONCLUSIONS}

Fat is the major component limiting the methanization of dairy wastewaters: fat is degraded after a lag phase, the length of which is several days, with a maximal degradation rate 2 to 5 times less than the degradation rate of the other milk components (lactose, proteins). This work improves the understanding of the mechanisms involved in the anaerobic degradation of milk fat: 1) The structure of the fat [globular (native state), triglycerides] does not influence the limits of its anaerobic degradation. 2) The lag phase before biogas production is mainly due to unsaturated FFA (encapsulation of biomass by adsorbed intermediate of oleate degradation), whereas the saturated FFA affect biogas production rate in a greater proportion than unsaturated FFA because of their lower solubility. Therefore, the prehydrolysis of fat, which increases the instantaneous concentration of unsaturated FFA, sharply increases the length of the lag phase with no significant change in the maximal biogas production rate. The low assimilability of milk fat, which leads to a low fat hydrolysis rate, contributes to reduce the accumulation of unsaturated FFA and therefore plays a protective role in unsaturated FFA inhibition. To reduce the inhibitory effect of fat degradation, it is necessary to reduce the concentration of unsaturated FFA. Further investigation in the saturation of unsaturated FFA by anaerobic or aerobic preacidification is certainly promising (Sage, 2005).

\section{ACKNOWLEDGMENTS}

The authors wish to thank Degrémont and Bretagne Biotechnologies Alimentaires for their financial support and Uzi Merin (Dairy Science Laboratory, Bet Dagan, Israel) for his critical proofreading of the manuscript.

\section{REFERENCES}

AFNOR French Standard. 1969. Lait- Fat content determinationethero-chloridric extraction method (Détermination de la teneur en Matières grasses-méthode par extraction éthérochlorhydrique). No. V04-215, Paris, France.

AFNOR French Standard. 1997. Water quality-suspended solid determination-centrifugation method (Qualité de l'eau-Dosage des matières en suspension-méthode par centrifugation). No. T-90-105-2, Paris, France.

AFNOR French Standard. 2001. Water quality-Determination of chemical oxygen demand (Qualité de l'eau-Détermination de la demande chimique en oxygène). No. NF T90-101, Paris, France.

Alves, M. M., J. A. M. Vieira, R. M. A. Pereira, M. A. Pereira, J. M. Novais, and M. Mota. 2001. Effects of lipids and oleic acid on biomass development in anaerobic fixed reactors. Part II: Oleic acid toxicity and biodegradability. Water Res. 35:264-270.

Cammarota, M. C., and D. M. G. Freire. 2006. A review on hydrolytic enzymes in the treatment of wastewater with high oil and grease content. Bioresour. Technol. 97:2195-2210.

Cammarota, M. C., G.A. Teixeira, and D. M. G. Freire. 2001. Enzymatic pre-hydrolysis and anaerobic degradation of wastewaters with high fat contents. Biotechnol. Lett. 23:1591-1595.

Gutierrez, J. L. R., P. A. G. Encina, and F. Fdz-Polanco. 1991. Anaerobic treatment of cheese-production wastewater using a UASB Reactor. Bioresour. Technol. 37:271-276. 
Hanaki, K., T. Matsuo, and M. Nagase. 1981. Mechanism of inhibition caused by long-chain fatty acids in anaerobic digestion process. Biotechnol. Bioeng. 23:1591-1610.

Kim, S.-H., S.-K. Han, and H.-S. Shin. 2004. Kinetics of LCFA inhibition on acetoclastic methanogenesis, propionate degradation and B-oxidation. J. Environ. Sci. Health A 39:1025-1037.

Komatsu, T., K. Hanaki, and T. Matuso. 1991. Prevention of lipid inhibition in anaerobic processes by introducing a two-phase system. Water Sci. Technol. 23:1189-1200.

Koster, I. W., and A. Cramer. 1987. Inhibition of methanogenesis from acetate in granular sludge by long chain fatty acids. Appl. Environ. Microbiol. 53:403-409.

Lalman, A. J., and D. M. Bagley. 2000. Anaerobic degradation and inhibitory effects of linoleic acid. Water Res. 34:4220-4228.

Lefebvre, X., E. Paul, M. Mauret, P. Baptiste, and B. Capdeville. 1998. Kinetic caracterisation of saponified domestic lipid residues aerobic biodegradation. Water Res. 32:3031-3038.

Li, A. Y., D. Kothari, and J. J. Corrado. 1984. Application of membrane anaerobic reactor system for the treatment of industrial wastewaters. Pages 627-636 in 39th Industrial Waste Conference, West Lafayette, IN.

Lopez, C. 2001. Contribution to triacylglycerol cristallization study: Application to milk emulsions (Contribution à l'étude de la cristallisation des triacylglycérols: Application aux émulsions laitières). PhD Thesis. Paris VI, France.

Loukidou, M. X., and A. I. Zouboulis. 2001. Biodegradability tests of dairy and cheese whey wastewaters using enzymes. Fresenius Environ. Bull. 10:188-192.

Mensah, K. A., and F. Forster. 2003. An examination of the effects of detergents on anaerobic digestion. Bioresour. Technol. 90:133138.

Moletta, R. 2006. Management of environmental issues in food industry (Gestion des problèmes environnementaux dans les industries agro-alimentaires). 2nd ed. Tec. et Doc. Lavoisier, Paris, France.

Omil, F., R. Mendez, and J. M. Lema. 1995. Anaerobic treatment of saline wastewaters under high sulphide and ammonia content. Bioresour. Technol. 54:269-278.
Pereira, M. A., O. C. Pires, M. Mota, and M. M. Alves. 2002. Anaerobic degradation of oleic acid by suspended and granular sludge: Identification of palmitic acid as a key intermediate. Water Sci. Technol. 45:139-144.

Pereira, M. A., O. C. Pires, M. Mota, and M. M. Alves. 2005. Anaerobic biodegradation of oleic and palmitic acids: Evidence of mass transfer limitations caused by long chain fatty acid accumulation onto the anaerobic sludge. Biotechnol. Bioeng. 92:15-23.

Pereira, M. A., D. Z. Sousa, M. Mota, and M. M. Alves. 2004 Mineralization of LCFA associated to anaerobic sludge: Kinetics, transport limitations, enhancement of methanogenic activity and effect of VFA. Biotechnol. Bioeng. 88:502-510.

Perle, M., S. Kimchie, and G. Shelef. 1995. Some biochemical aspects of the anaerobic degradation of dairy wastewater. Water Res. 29:1549-1554.

Petruy, R., and G. Lettinga. 1997. Digestion of a milk-fat emulsion. Bioresour. Technol. 61:141-149.

Rinzema, A., M. Boone, K. Van Kinppenberg, and G. Lettinga. 1994 Bactericidal effect of long chain fatty acids in anaerobic digestion. Water Environ. Res. 66:40-49.

Sage, M. 2005. Dairy process water valorisation through methanisation and denitrification (Valorisation des eaux de procédés de l'industrie laitière en méthanisation et denitrification). PhD Thesis. ENSA, Rennes, France.

Thierry, A., M. B. Maillard, and M. Yvon. 2002. Conversion of L-leucine to isovaleric acid by Propionibacterium freundenreichii TL 34 and ITGP23. Appl. Environ. Microbiol. 68:608-615.

Vidal, G., A. Carvalho, R. Méndez, and J. M. Lema. 2000. Influence of the content in fats and proteins on the anaerobic biodegradability of dairy wastewaters. Bioresour. Technol. 74:231-239.

Weng, C., and J. S. Jeris. 1976. Biochemical mechanisms in the methane fermentation of glutamic and oleic acids. Water Res. $10: 9-18$ 